University of Nebraska - Lincoln

DigitalCommons@University of Nebraska - Lincoln

\title{
Kinetics of Reductive Dissolution of Hematite by Bioreduced Anthraquinone-2,6-disulfonate
}

\author{
Chongxuan Liu \\ Pacific Northwest National Laboratory, chongxuan.liu@pnl.gov \\ John M. Zachara \\ Pacific Northwest National Laboratory, john.zachara@pnl.gov \\ Nancy Foster \\ Pacific Northwest National Laboratory, nancy.foster@pnl.gov \\ Janae Strickland \\ Pacific Northwest National Laboratory
}

Follow this and additional works at: https://digitalcommons.unl.edu/usdoepub

Part of the Bioresource and Agricultural Engineering Commons

Liu, Chongxuan; Zachara, John M.; Foster, Nancy; and Strickland, Janae, "Kinetics of Reductive Dissolution of Hematite by Bioreduced Anthraquinone-2,6-disulfonate" (2007). US Department of Energy Publications. 234.

https://digitalcommons.unl.edu/usdoepub/234

This Article is brought to you for free and open access by the U.S. Department of Energy at DigitalCommons@University of Nebraska - Lincoln. It has been accepted for inclusion in US Department of Energy Publications by an authorized administrator of DigitalCommons@University of Nebraska - Lincoln. 


\section{Kinetics of Reductive Dissolution of Hematite by Bioreduced Anthraquinone-2,6-disulfonate}

\author{
CHONGXUAN LIU, * JOHN M. ZACHARA, \\ NANCY S. FOSTER, AND \\ J A NAE STR I C KLAND \\ Pacific Northwest National Laboratory, P.O. Box 999, \\ MS K8-96, Richland Washington 99352
}

The reductive dissolution of hematite $\left(\alpha-\mathrm{Fe}_{2} \mathrm{O}_{3}\right)$ was investigated in a flow-through system using $\mathrm{AH}_{2} \mathrm{DS}$, a reduced form of anthraquinone-2,6-disulfonate (AQDS), which is often used as a model electron shuttling compound in studies of dissimilatory microbial reduction of iron oxides. Influent flow rate, $\mathrm{pH}$, and $\mathrm{Fe}(\mathrm{II})$ and phosphate concentrations were varied to investigate the redox kinetics in a flow-through reactor. The hematite reduction rates decreased with increasing $\mathrm{pH}$ from 4.5 to 7.6 and decreased with decreasing flow rate. The rates also decreased with increasing influent concentration of $\mathrm{Fe}(\mathrm{II})$ or phosphate that formed surface complexes at the experimental $\mathrm{pH}$. Mineral surface properties, Fe(II) complexation reactions, and AODS sorption on hematite surfaces were independently investigated for interpreting hematite reduction kinetics. $\mathrm{AH}_{2} \mathrm{DS}$ sorption to hematite was inferred from the parallel measurements of AODS and $\mathrm{AH}_{2} \mathrm{DS}$ sorption to $\alpha-\mathrm{Al}_{2} \mathrm{O}_{3}$, a redox stable analog of $\alpha-\mathrm{Fe}_{2} \mathrm{O}_{3}$. Decreasing $\mathrm{Fe}(\mathrm{II})$ and increasing $\mathrm{AH}_{2} \mathrm{DS}$ sorption by controlling flow rate, influent $\mathrm{pH}$, and $\mathrm{Fe}(\mathrm{II})$ and phosphate concentrations increased the rates of reductive dissolution. The rates were also affected by the redox reaction free energy when reductive dissolution approached equilibrium. This study demonstrated the importance of the geochemical variables for the reductive dissolution kinetics of iron oxides.

\section{Introduction}

The microbial reduction of iron oxides is an important process in the biogeochemical cycling of iron in natural environments. The iron biogeochemical cycle is of global significance because of the abundance and high surface reactivity of iron oxides and its coupling with the biogeochemical cycles of $\mathrm{C}$, $\mathrm{O}, \mathrm{P}, \mathrm{S}$, and metals. The reduction of iron oxides is frequently mediated by dissimilatory iron reducing bacteria (DIRB) in anoxic, water-rock systems (e.g., refs 1 and 2). DIRB have evolved different strategies to utilize Fe(III) oxides as electron acceptors. Geobacter metallireducens produces flagella and pili that allow cellular transport and attachment to the Fe(III) oxide surface, after which direct electron transfer occurs through electron transducing proteins $(3,4)$. In contrast and under certain conditions, Shewanella and Geothrix species produce undefined, soluble, extracellular electron shuttling compounds that can mediate electron transfer to Fe(III) oxides $(4,5)$. In spite of these adaptive access strategies, the bioreduction of crystalline Fe(III) oxides is generally slow, and reduction extent is typically limited.

* Corresponding author (509)376-0129; fax: (509)376-3650; email: chongxuan.liu@pnl.gov.
Exogenous electron accepting/donating compounds, including quinones and humic substances, can significantly enhance the rate and extent of Fe(III) oxide reduction. The influence of these electron shuttling compounds (ESC) has been extensively studied (e.g., refs 4 and 6-8), most often using anthraquinone-2,6-disulfonate (AQDS) as a model ESC. The oxidized form of the ESC (e.g., AQDS) is reduced by DIRB, and the reduced form (e.g., $\mathrm{AH}_{2} \mathrm{DS}$ ) transports electrons to the Fe(III) oxide where it is oxidized through heterogeneous electron transfer. The oxidized ESC may again be reduced by respiring DIRB. This cyclic kinetics continues until the electron donor/acceptor or other necessary nutrients are exhausted, or the reaction ceases for thermodynamic or other reasons. AQDS has been shown to be a particularly effective ESC because of its low half-cell potential and apparently facile redox kinetics in both forward and reverse directions. While AQDS is known to enhance the reduction of Fe(III) oxides by DIRB (9), its redox kinetics at the Fe(III) oxide interface is not well characterized.

In this paper, we report on the reduction kinetics of hematite $\left(\alpha-\mathrm{Fe}_{2} \mathrm{O}_{3}\right)$ by $\mathrm{AH}_{2} \mathrm{DS}$ under conditions of variable, but controlled $\mathrm{pH}$, flow rate, and $\mathrm{Fe}(\mathrm{II})$ and phosphate concentrations in a flow-through system. Independent experiments were conducted to determine $\mathrm{H}^{+}, \mathrm{Fe}(\mathrm{II}), \mathrm{AQDS}$, and $\mathrm{AH}_{2} \mathrm{DS}$ sorption to hematite for interpreting reduction kinetic data.

\section{Experimental Procedures}

Materials. $\mathrm{AH}_{2} \mathrm{DS}$ was generated through bioreduction of AQDS with $\mathrm{H}_{2}$ as electron donor in a culture of Shewanella putrefaciens strain CN32. Chemical reduction was tried but not able to completely reduce AQDS to $\mathrm{AH}_{2} \mathrm{DS}$. The AQDS culture $(100 \mathrm{~mL})$, which contained $2-4 \times 10^{8}$ cells $/ \mathrm{mL}, 1-5$ mM AQDS, $20 \mathrm{~mL}$ of $\mathrm{H}_{2}$, and $10 \mathrm{mM}$ PIPES buffer at $\mathrm{pH} 6.8$ in a $100 \mathrm{~mL}$ serum bottle, was incubated at $30^{\circ} \mathrm{C}$ and $10 \mathrm{rpm}$ for 5-7 days until a color change (to orange) indicated AQDS conversion to $\mathrm{AH}_{2} \mathrm{DS}$. The $\mathrm{AH}_{2} \mathrm{DS}$ solution was filtered $(0.2$ $\mu \mathrm{m})$ anaerobically into a sterile serum bottle and stoppered. The reduction of AQDS to $\mathrm{AH}_{2} \mathrm{DS}$, which involves a twoelectron transfer

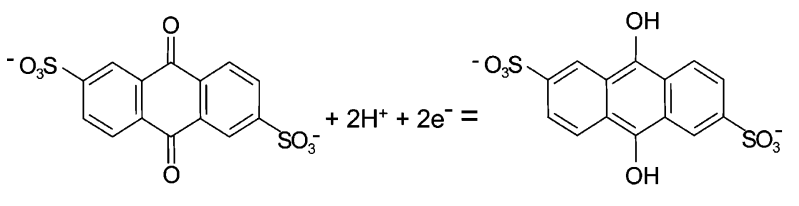

$$
\text { AQDS }
$$

$\mathrm{AH}_{2} \mathrm{DS}$

anthraquinone-2-6-disulfonate

anthrahydroquinone-2-6-disulfonate

was confirmed by UV-vis absorption spectroscopy (Agilent, HP8452A spectrometer). $\mathrm{AH}_{2} \mathrm{DS}$ and AQDS concentrations were determined from their absorbance near 400 and 326 $\mathrm{nm}$ with a detection limit of $1 \mu \mathrm{M}$. The molar extinction coefficients and UV-vis spectra for $\mathrm{AH}_{2} \mathrm{DS}$ and AQDS at different $\mathrm{pHs}$ were provided in Table $\mathrm{S} 1$ and Figure $\mathrm{S} 1$ in the Supporting Information.

Two hematite samples were used: one was a pigment hematite (RP200M) purchased from Delta Colours, Lawrenceville, GA, and the other was synthetically prepared 2UM hematite via the hydrolysis of Fe(III) in a strongly alkaline media under hydrothermal conditions (10). The hematite was rinsed 5 times with DI water and air-dried. The crystallinity of the hematite was confirmed by X-ray diffraction. 
$\alpha$-Aluminum oxide was used as a hematite analog to study $\mathrm{AH}_{2} \mathrm{DS}$ adsorption. The $\alpha-\mathrm{Al}_{2} \mathrm{O}_{3}(2.5 \mathrm{~g})$, which was purchased from Alfa Aesar, was washed in $250 \mathrm{~mL}$ of $0.01 \mathrm{M} \mathrm{NaOH}$ to dissolve fine-grained impurities, ultrasonicated for $5 \mathrm{~min}$, and agitated for $25 \mathrm{~min}$. The solids were then collected by centrifugation; washed and ultrasonicated in $0.01 \mathrm{M} \mathrm{NaClO}_{4}$ three times; centrifuged, decanted, and resuspended in DI water with ultrasonication; and placed into dialysis tubing. The dialysate was replaced daily until the conductivity was $<1.0 \mu \mathrm{S} / \mathrm{cm}$. The slurry was freeze-dried. After this treatment, the particles ranged from 0.2 to $1.6 \mu \mathrm{m}$ in diameter with a surface area of $4.4 \mathrm{~m}^{2} / \mathrm{g}$ and contained no detectable impurities. $\mathrm{Al}_{2} \mathrm{O}_{3}$ has a reported point of zero net proton charge $\left(\mathrm{pH}_{\mathrm{PZNPC}}\right) \cong 8.0-9.3$ (11).

Acid-Base and Electrolyte Titration. Hematite suspensions $(5.2 \mathrm{~g} / \mathrm{L})$ were titrated with acid-base over a $\mathrm{pH}$ range of 4.5-9.3 at different ionic strengths $(1,10$, and $100 \mathrm{mM})$. The hematite samples were washed repeatedly ( $\sim 8$ times) in $0.01 \mathrm{M} \mathrm{NaNO}_{3}$ until the $\mathrm{pH}$ stabilized. The stabilized $\mathrm{pH}$ was 4.7 for RP200M and 5.9 for 2UM. The washed hematite was resuspended and sonicated in $0.01 \mathrm{M} \mathrm{NaNO}_{3}$ and brought into a $\mathrm{N}_{2}$-purged environmental chamber (Innovative Technologies) and diluted to $250 \mathrm{~mL}$ with deoxygenated water into a water jacketed cell, which kept the suspension at 26 ${ }^{\circ} \mathrm{C}$. The suspension was stirred and purged with hydrated $\mathrm{N}_{2}$ (to exclude $\mathrm{CO}_{2}$ ) for $1 \mathrm{~h}$ prior and continuously during the titration. An autotitrator (Metrohm, 736 GP Titrino) was used to add aliquots of $0.01 \mathrm{M} \mathrm{HNO}_{3}$ or $\mathrm{NaOH}$ with a rate of 0.1 $\mathrm{mL} /$ data point. The equilibrium $\mathrm{pH}$ was recorded when the signal drift was less than $2 \mathrm{mV} / \mathrm{min}$. The $\mathrm{pH}$ was monitored using a combination glass electrode.

Electrolyte titration was performed to resolve the hematite $\mathrm{pH}_{\text {PZNPC }}$ that was ambiguous in acid-base titration (11). Hematite $\left(1.3 \mathrm{~g}\right.$ ) was washed in $0.01 \mathrm{M} \mathrm{NaNO}_{3}$ until a constant $\mathrm{pH}$ was obtained as described above. The washed sample was brought into the $\mathrm{N}_{2}$-purged chamber and suspended in $250 \mathrm{~mL}$ of $0.01 \mathrm{M} \mathrm{NaNO}_{3}$. Each hematite suspension was adjusted to $\mathrm{pH} 8.5$ in a water jacketed cell $\left(26^{\circ} \mathrm{C}\right)$, stirred, and purged continuously with $\mathrm{N}_{2}$ until pH stabilized $(90 \mathrm{~h}$ for RP200M and $100 \mathrm{~h}$ for $2 \mathrm{UM}$ ). After the $\mathrm{pH}$ stabilized, a $20 \mathrm{~mL}$ aliquot was removed, placed in a plastic tube, then adjusted to a desired $\mathrm{pH}$ value (6.5-9), and purged with $\mathrm{N}_{2}$ until the $\mathrm{pH}$ stabilized again (approximately $30 \mathrm{~min}$ ). Salt $\left(1.7 \mathrm{~g} \mathrm{NaNO}_{3}\right)$ was added to the stabilized suspensions, and $\mathrm{pH}$ was monitored until re-equilibration (30-60 min). The difference in $\mathrm{pH}(\Delta \mathrm{pH})$ due to the addition of $\mathrm{NaNO}_{3}$ was plotted as a function of initial $\mathrm{pH}$. The $\mathrm{pH}_{\mathrm{PZNPC}}$ was determined at $\Delta \mathrm{pH}=0$.

Fe(II) Sorption. Adsorption of Fe(II) to hematite (2.6 g/L) was measured as a function of $\mathrm{pH}$ in $0.1 \mathrm{M} \mathrm{NaNO}_{3}$ solution at $26{ }^{\circ} \mathrm{C}$ according to a method described in ref 12 . The experimental setup was identical to the acid-base titration. The washed hematite was suspended in $250 \mathrm{~mL}$ of deoxygenated $0.1 \mathrm{M} \mathrm{NaNO}_{3}$ solution containing a desired concentration of $\mathrm{Fe}$ (II) in a $\mathrm{N}_{2}$-purged chamber. The suspension $\mathrm{pH}$ was initially adjusted to 4.5 with $0.01 \mathrm{M} \mathrm{HNO}_{3}$ and then titrated from $\mathrm{pH} 4.5$ to 9.3 with $0.01 \mathrm{M} \mathrm{NaOH}$. The suspension was allowed to equilibrate after each base addition until the $\mathrm{pH}$ stability criteria was met $(\leq 2 \mathrm{mV} / \mathrm{min})$. At selected $\mathrm{pH}$ points, a $2 \mathrm{~mL}$ aliquot was taken using a syringe and immediately filtered using $0.02 \mu \mathrm{m}$ membrane filter (Whatman, 6809-6002). The filtrate was diluted with $2 \% \mathrm{HNO}_{3}$, and its Fe concentration was measured using ICP-MS with a detection limit of $20 \mu \mathrm{g} / \mathrm{L}$. The amount of sorbed Fe(II) was calculated from the difference between total and aqueous $\mathrm{Fe}(\mathrm{II})$ in the suspension.

AQDS and $\mathbf{A H}_{2}$ DS Sorption. AQDS sorption to hematite $(100 \mathrm{~g} / \mathrm{L})$ was determined at $\mathrm{pH} 4.5$ and 6.9 as a function of AQDS concentration $(25-375 \mu \mathrm{M})$ in $0.1 \mathrm{M} \mathrm{NaNO}_{3}$ electrolyte with $10 \mathrm{mM} \mathrm{pH}$ buffer [acetate for $\mathrm{pH} 4.5$ and 1,4- piperazinediethanesulfonic acid (PIPES) for $\mathrm{pH}$ 6.9] in the $\mathrm{N}_{2}$-purged chamber. After equilibration (5 min, minimum equilibrium time), the solution was filtered with a $0.22 \mu \mathrm{m}$ pore size syringe filter for AQDS measurements. The sorbed AQDS was calculated from the difference of initial and final aqueous AQDS concentrations.

Direct measurements of $\mathrm{AH}_{2} \mathrm{DS}$ sorption to hematite were not successful because of the rapid oxidation of $\mathrm{AH}_{2} \mathrm{DS}$ by hematite. Consequently, the sorption of $\mathrm{AH}_{2} \mathrm{DS}$ and AQDS on $\alpha-\mathrm{Al}_{2} \mathrm{O}_{3}$, a redox inert structural analog of $\alpha-\mathrm{Fe}_{2} \mathrm{O}_{3}$, was measured under the same conditions as used for hematite.

Redox Experiments. Hematite reduction by $\mathrm{AH}_{2} \mathrm{DS}$ was investigated in a flow-through reactor at variable but controlled $\mathrm{pH}$ and flow rates with and without added Fe(II) or phosphate in influent solution. Constant $\mathrm{pH}$ was maintained in each specific experiment with $10 \mathrm{mM}$ pH buffer: acetate at $\mathrm{pH} 4.5$ and 5.6, PIPES at $\mathrm{pH} 6.9$, and $\mathrm{N}$-2hydroxyethylpiperazine- $N^{\prime}$-2-ethanesulfonic acid (HEPES) at $\mathrm{pH}$ 7.6. All experiments were performed in the $\mathrm{N}_{2}$-purged chamber.

The flow-through apparatus was shown in Figure S2 in the Supporting Information, which consisted of a solution reservoir, a peristaltic pump, two parallel reactors (one empty and the other containing hematite), and valves to control flow through only one reactor at a time. The hematite reactor contained a $0.75 \mathrm{mg}$ hematite sample, which existed as a thin film ( $<0.3 \mathrm{~mm}$ thickness) on a $0.22 \mu \mathrm{m}$ filter supported by a screen. The solution from the reactors passed through a cuvette (Hellma, 176.700-QS) mounted in the UV-vis spectrometer for periodic measurements of AQDS and $\mathrm{AH}_{2-}$ DS.

Initially DI water was pumped through the empty reactor to register a baseline UV-vis spectra, which was followed by the $\mathrm{AH}_{2} \mathrm{DS}$ solution $\left(\mathrm{AH}_{2} \mathrm{DS}=50 \mathrm{mM}\right.$ and AQDS $\left.=0 \mathrm{mM}\right)$ until a constant absorbance was achieved in the effluent. The valves were then switched to allow $\mathrm{AH}_{2} \mathrm{DS}$ solution to contact hematite. UV-vis absorbance spectra $(200-600 \mathrm{~nm})$ were collected online to determine effluent $\mathrm{AH}_{2} \mathrm{DS}$ and AQDS concentrations. The effluent was accumulated and collected every $30 \mathrm{~min}$ for measurements of $\mathrm{Fe}_{\text {tot }}$ with ICP-MS. Selected effluent samples were measured using the ferrozine technique (13) to determine Fe(II) concentration. No Fe(III) was detected from any of the effluent solutions. Because hematite existed as a thin film in the reactor, the averaged concentrations in influent and effluent solutions were used as approximate residence concentrations in the following data analysis.

\section{Results and Discussion}

Hematite Properties. Hematite RP200M and 2UM were well crystallized and free of crystallographic impurities. Both hematite samples were hexagonal, but RP200M was smaller in size and had a higher surface area than 2UM (Table 1). The $\mathrm{pH}_{\mathrm{PZNPC}}$ determined from acid-base and electrolyte titrations were 7.2 for RP200M and 7.4 for 2UM (Table 1). These $\mathrm{pH}$ PZNPC values are slightly lower than those often reported for hematite $(\sim 7.5-8.5)$ but were reproducible and within the range of published values (3.0-9.5) (11).

$\mathbf{F e}($ II) Sorption. Fe(II) sorption to hematite increased with increasing $\mathrm{pH}$ above $\mathrm{pH} 5.5$ (Figure 1). The correspondent acid-base titration profiles with and without Fe(II) were provided in Figure S5 in the Supporting Information. The Fe(II) sorption data were described with a surface complexation model that was detailed and characterized using the acid-base titration data in Figure S5 in the Supporting Information. The model reasonably well described all Fe(II) sorption data below pH 7 (Figure 1). It well described Fe(II) sorption over the entire $\mathrm{pH}$ range $(4.5-9.3)$ in the $2 \mathrm{UM}$ hematite suspension containing $3.4 \times 10^{-5} \mathrm{M} \mathrm{Fe}(\mathrm{II})$ but underpredicted sorption above $\mathrm{pH} 8$ in the $2 \mathrm{UM}$ hematite suspension with $6.8 \times 10^{-5} \mathrm{M} \mathrm{Fe}(\mathrm{II})$ and above $\mathrm{pH} 7$ in the 


\section{TABLE 1. Properties of RP200M and 2UM Hematite.}

$\begin{array}{lll}\text { parameter } & \text { RP200M } & \text { 2UM }\end{array}$

source Delta Colours

hydrolyzis of $\mathrm{Fe}(\mathrm{III})$ in a strongly alkaline media under hydrothermal conditions

surface area, $\quad 10.05 \mathrm{~m}^{2} / \mathrm{g}$ $2.91 \mathrm{~m}^{2} / \mathrm{g}$ BET-Kr

surface area, $10.75 \mathrm{~m}^{2} / \mathrm{g}$

$3.44 \mathrm{~m}^{2} / \mathrm{g}$

BET-N2

morphologya pseudohexagonal tabular hexagonal plates color

diameter

$\mathrm{pH}_{\mathrm{PZNPC}}{ }^{b}$ red

$0.2 \mu \mathrm{m}$

purple

$2-6 \mu \mathrm{m}$

7.4

a See TEM images in Figure S3 in the Supporting Information. ${ }^{b} \mathrm{pH}_{\text {PZNPC }}$ for RP200M was averaged from those determined from acidbase titration $(\mathrm{pH} \mathrm{7.25)}$ and electrolyte titration $(\mathrm{pH} 7.1$, Figure $\mathrm{S} 3$ in the Supporting Information). $\mathrm{pH}_{\mathrm{PZNPC}}$ for $2 \mathrm{UM}$ was determined from electrolyte titration (Figure S3 in the Supporting Information), because the acid-base titration displayed hysteresis when titration went from $\mathrm{pH} 4.5$ to 9.3 and back to $\mathrm{pH} 4.5$.

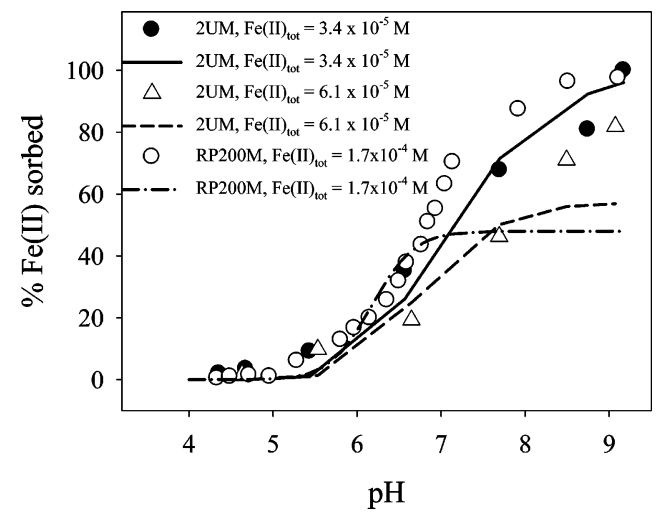

FIGURE 1. Sorption of $\mathrm{Fe}$ (II) on hematite as a function of $\mathrm{pH}$ and $\mathrm{Fe}$ (II) concentration. The symbols are data, and lines were calculated with a $\mathrm{Fe}$ (II) surface complexation model that was described in the Supporting Information. The sorption experiments were performed in $0.1 \mathrm{M} \mathrm{NaNO}_{3}$ with $0.65 \mathrm{~g}$ of hematite $/ 250 \mathrm{~mL}$ at $26{ }^{\circ} \mathrm{C}$.

RP200M suspension with $1.7 \times 10^{-4} \mathrm{M}$ Fe(II) (Figure 1). The calculated Fe(II) sorption deviated increasingly from the measured values with increasing $\mathrm{pH}$. Such deviations have previously been attributed to the surface precipitation of magnetite (14) or $\mathrm{Fe}(\mathrm{OH})_{2}$ (s) (15). Speciation calculations (Figure S6 in the Supporting Information) suggest that magnetite was saturated above $\mathrm{pH} 7$ and $\mathrm{Fe}(\mathrm{OH})_{2}$ (s) was saturated above $\mathrm{pH} 9$ in hematite suspensions containing over $6.1 \times 10^{-5} \mathrm{M}$ Fe(II).

AQDS and $\mathrm{AH}_{2}$ DS Sorption. The sorption of AQDS and $\mathrm{AH}_{2} \mathrm{DS}$ was $\mathrm{pH}$ dependent (Figure 2). AQDS sorption on hematite was markedly higher at $\mathrm{pH} 4.5$ than $\mathrm{pH} 6.9$ (Figure $2 \mathrm{a}, \mathrm{b})$, as was the sorption of both AQDS and $\mathrm{AH}_{2} \mathrm{DS}$ on $\alpha-\mathrm{Al}_{2} \mathrm{O}_{3}$ (Figure 2c). At $\mathrm{pH} 4.5$, AQDS and $\mathrm{AH}_{2} \mathrm{DS}$ sorption isotherms on $\alpha-\mathrm{Al}_{2} \mathrm{O}_{3}$ nearly converged. At $\mathrm{pH}$ 6.9, $\mathrm{AH}_{2} \mathrm{DS}$ sorbed more strongly than AQDS.

The sorption isotherms of AQDS and $\mathrm{AH}_{2} \mathrm{DS}$ (Figure 2) were described using the Langmuir model that was detailed in the Supporting Information. The Langmuir model consists of two parameters: total site concentration $S_{\mathrm{T}}$ and affinity constant $b$. The linkage of the affinity constant $b$ with the surface complexation reaction constant was also provided in the Supporting Information. The $S_{\mathrm{T}}$ derived from AQDS sorption measurements on hematite was 2.56 and 1.03 $u \mathrm{~mol} / \mathrm{g}$ for RP200M and 2UM, respectively, which were over $6-10$ times less than that estimated from acid-base titration (18.5 and $13.4 \mu \mathrm{mol} / \mathrm{g}$ for RP200M and 2UM, respectively).
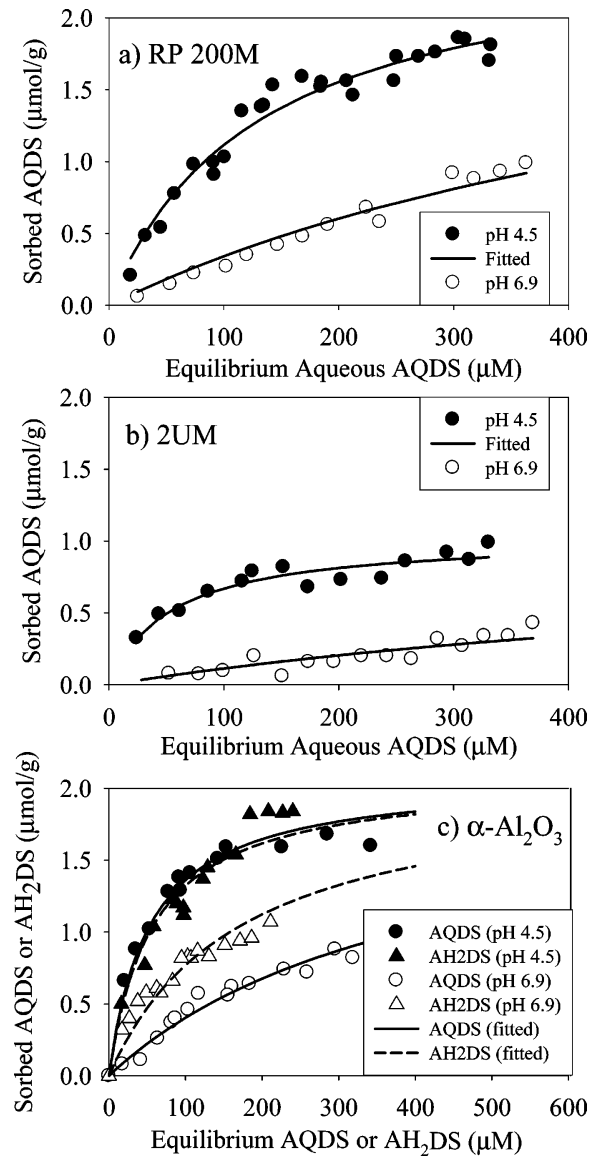

FIGURE 2. Sorption isotherms of AODS on hematite of (a) RP200M and (b) $2 \mathrm{UM}$ and sorption isotherms of $A Q D S$ and $\mathrm{AH}_{2} \mathrm{DS}$ on $\alpha-\mathrm{Al}_{2} \mathrm{O}_{3}$ (c). Symbols are the data, and lines are fitted with the Langmuir model described in the Supporting Information.

The $\mathrm{pH}$ buffer may have weakly sorbed in these sorption experiments, which could affect the affinity constants, but it should have a minimal effect on the site density because it was determined by the isotherm data near surface saturation. The site density values determined from acidbase titration were 1.11 and 2.78 sites $/ \mathrm{nm}^{2}$ after normalizing to surface area for RP200M and 2UM, respectively, which were close to literature values, e.g., $2.07 \mathrm{site} / \mathrm{nm}^{2}$ (12), suggesting that $\mathrm{AQDS} / \mathrm{AH}_{2} \mathrm{DS}$ surface complexation required specific selective sites. Charge repulsion between nearby sorbed $\mathrm{AQDS} / \mathrm{AH}_{2} \mathrm{DS}$ and/or steric effects may also be the reasons for the differences in the estimated site densities.

The sorption of AQDS/ $\mathrm{AH}_{2} \mathrm{DS}$ to hematite was weak. For example, the distribution coefficient $\left(K_{\mathrm{d}}\right)$ for the linear parts of AQDS $/ \mathrm{AH}_{2} \mathrm{DS}$ sorption isotherms was calculated $\left(K_{\mathrm{d}}=\right.$ $\left.S_{\mathrm{T}} / b\right)$ to be $18-20 \mathrm{~L} / \mathrm{kg}$ at $\mathrm{pH} 4.5$ and $4-10 \mathrm{~L} / \mathrm{kg}$ at $\mathrm{pH} 6.9$. The calculated $K_{\mathrm{d}}$ values for the linear parts of $\mathrm{SO}_{4}{ }^{2-}$ sorption isotherms were 680 and $160 \mathrm{~L} / \mathrm{kg}$ at $\mathrm{pH} 3$ and 7, respectively (16). The weak AQDS/AH ${ }_{2} \mathrm{DS}$ sorption was expected because sulfonate $(17,18)$ and quinone groups $(19)$ react with mineral surfaces through outer sphere complexation. The higher sorption of anionic $\mathrm{AQDS}$ and $\mathrm{AH}_{2} \mathrm{DS}$ at $\mathrm{pH} 4.5$ (Figure 2c) resulted from the more positively charged hematite surface at the lower $\mathrm{pH}$ that led to stronger electrostatic retention. The $\mathrm{AH}_{2} \mathrm{DS}$ phenol groups may have enhanced its sorption over AQDS at pH 6.9 (Figure 2c). Calculations showed that $5-25 \%$ of the first phenol group on $\mathrm{AH}_{2} \mathrm{DS}\left[\mathrm{p} K_{\mathrm{al}}=7.4-8.1\right.$ $(20,21)]$ was depronated at $\mathrm{pH} 6.9$, providing additional electrostatic potential for sorption. At $\mathrm{pH} 4.5$, both phenol groups were protonated.

Redox Reactions between $\mathrm{AH}_{2} \mathrm{DS}$ and Hematite. Figure 3 shows typical effluent concentrations of $\mathrm{AH}_{2} \mathrm{DS}$, AQDS, 


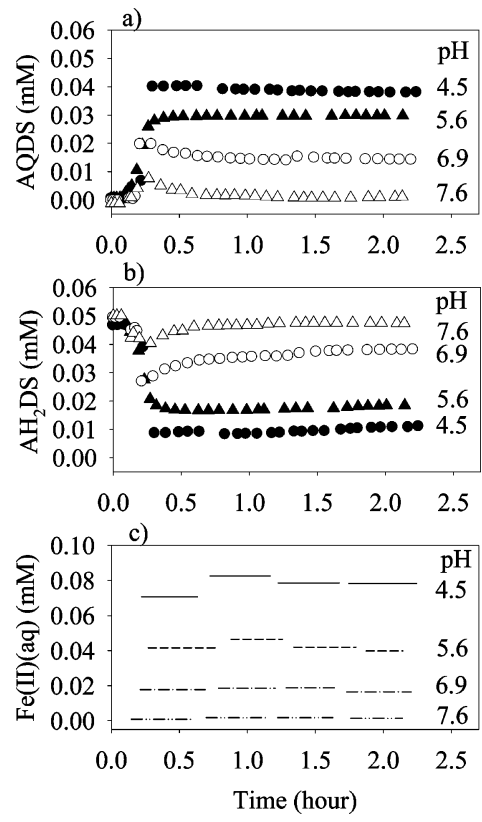

FIGURE 3. An example of effluent data for the reaction of $\mathrm{AH}_{2} \mathrm{DS}$ with hematite: (a) AODS, (b) $\mathrm{AH}_{2} \mathrm{DS}$, and (c) aqueous $\mathrm{Fe}$ (II) as a function of time and $\mathrm{pH}$. This specific example used RP200M hematite and a flow rate of about $92 \mu \mathrm{L} / \mathrm{min}$. The lines in plot $\mathrm{c}$ are the effluent $\mathrm{Fe}$ (II) concentrations measured from composite samples. The line length represents the time interval in collecting the composite samples.

and Fe(II) for all redox experiments. The effluent concentrations of AQDS and $\mathrm{AH}_{2} \mathrm{DS}$ changed significantly within the first half hour of $\mathrm{AH}_{2} \mathrm{DS}$ contact with hematite and then evolved toward steady state. The Fe(II) concentration (Figure 3c) was measured using 30 min composited effluent samples, and it changed slightly with time. No measurable $\mathrm{pH}$ differences were observed between influent and effluent solutions in all experiments.

The steady-state rate of $\mathrm{AH}_{2} \mathrm{DS}$ reduction of hematite was calculated from the difference of influent and steady-state effluent concentrations of $\mathrm{AH}_{2} \mathrm{DS}$, AQDS, or $\mathrm{Fe}(\mathrm{II})$

$$
R=q\left(C^{\mathrm{e}}-C^{\mathrm{i}}\right)
$$

where $R$ is the reaction rate ( $\mathrm{mol} / \mathrm{min}$ ), $q$ is the liquid flow rate $(\mathrm{L} / \mathrm{min})$, and $C^{\mathrm{i}}$ and $C^{\mathrm{e}}$ are the influent and effluent concentrations (mol/L), respectively. The effluent concentrations after $1 \mathrm{~h}$ of elution were averaged as the steady-state concentrations. The calculated rates and their ratios for all the redox experiments were provided in Tables S4 and S5 in the Supporting Information.

Reaction Stoichiometry. Mass balance between the influent and effluent total AQDS concentration, $\mathrm{Q}\left(\mathrm{Q}=\left[\mathrm{AH}_{2} \mathrm{DS}\right]+-\right.$ [AQDS]), and a one-to-one ratio of AQDS production to $\mathrm{AH}_{2}$ DS consumption were observed at steady-state in all experiments (Tables S4 and S5). The mass balance data indicated that $\mathrm{AH}_{2} \mathrm{DS}$ was quantitatively oxidized to AQDS and that the intermediate radical species (AHDS) was either not present or its concentration was negligible. UV-vis spectra consistent with those reported for sulfonated semiquinone radicals (21) were not observed. The 1:1 ratio of AQDS production and $\mathrm{AH}_{2} \mathrm{DS}$ consumption suggested the following redox reaction stoichiometry

$$
\mathrm{AH}_{2} \mathrm{DS}^{2-}+\mathrm{Fe}_{2} \mathrm{O}_{3}+4 \mathrm{H}^{+}=\mathrm{AQDS}^{2-}+2 \mathrm{Fe}^{2+}+3 \mathrm{H}_{2} \mathrm{O}
$$

The measured ratio for $R_{\mathrm{Fe}(\mathrm{II})} / R_{\mathrm{AODS}}$ and $-R_{\mathrm{Fe}(\mathrm{II})} / R_{\mathrm{AH} 2 \mathrm{DS}}$ at $\mathrm{pH}$ 4.5 and 5.6 was nearly 2:1 (Tables S4 and S5), thereby supporting reaction 3 stoichiometry. However, the ratio of
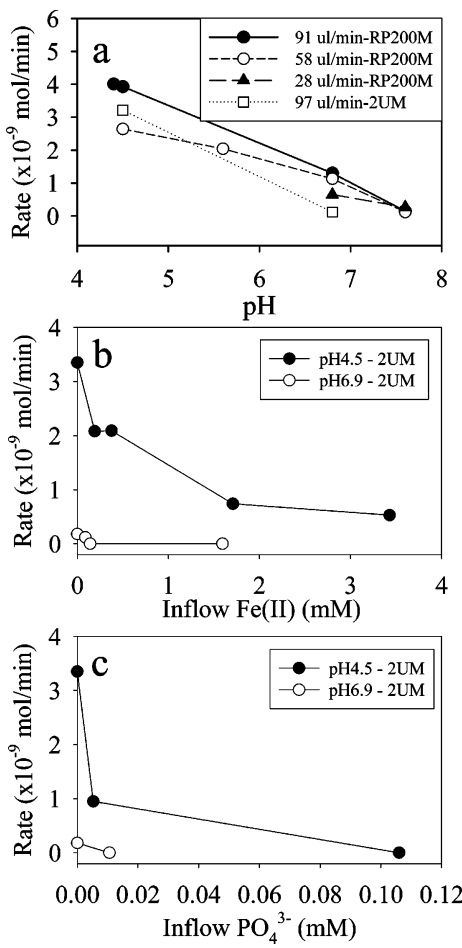

FIGURE 4. Influence of experimental factors on the rate of hematite reduction by $\mathrm{AH}_{2} \mathrm{DS}$ (original data in Tables $\mathrm{S} 4$ and $\mathrm{S} 5$ in the Supporting Information): (a) $\mathrm{pH}$ and flow rate; (b) influent $\mathrm{Fe}$ (II) concentration; and (c) influent $\mathrm{PO}_{4}{ }^{3-}$ concentration. The lines are shown only to connect like symbols.

$R_{\mathrm{Fe}(\mathrm{II})} / R_{\mathrm{AQDS}}$, or $-R_{\mathrm{Fe}(\mathrm{II})} / R_{\mathrm{AH} 2 \mathrm{DS}}$, or both was below $2: 1$ at circumneutral $\mathrm{pH}$ (6.9 or 7.6). The lower ratios near neutral $\mathrm{pH}$ suggested that the $\mathrm{Fe}(\mathrm{II})$ produced was involved in additional reactions (e.g., precipitation) beyond surface complexation. The Fe(II) sorption data also suggested Fe(II) precipitation at high $\mathrm{pH}$ (Figure 1) as described before. For discussion convenience in the following analysis, rates calculated from $\mathrm{AH}_{2} \mathrm{DS}$ consumption were used to describe the rates of $\mathrm{AH}_{2} \mathrm{DS}$ oxidation and hematite reduction.

Influence of $p H$. The steady-state rates of hematite reduction increased with decreasing $\mathrm{pH}$ under comparable flow-rate conditions (Figure 4a). A pH-dependent reduction rate was also observed for the reductive dissolution of hematite by hydroquinone that was attributed to the increasing adsorption of reductant at low $\mathrm{pH}$ (22). Calculations using (i) the $\mathrm{AH}_{2} \mathrm{DS}$ residence concentration in the reactor (the average of influent and effluent $\mathrm{AH}_{2} \mathrm{DS}$ concentrations as defined before) and (ii) the Langmuir model described in the Supporting Information showed that the sorbed $\mathrm{AH}_{2} \mathrm{DS}$ concentration increased from $0.36 \mu \mathrm{mol} / \mathrm{g}$ at pH 6.9 to $0.49 \mu \mathrm{mol} / \mathrm{g}$ at $\mathrm{pH} 4.5$ for RP200M. This occurred in spite of the lower residence aqueous concentration of $\mathrm{AH}_{2} \mathrm{DS}$ at $\mathrm{pH} 4.5(33.5 \mu \mathrm{M}$ at a flow of $92 \mu \mathrm{L} / \mathrm{min})$ than at $\mathrm{pH}$ $6.9(43.6 \mu \mathrm{M}$ at a flow of $93 \mu \mathrm{L} / \mathrm{min})$. This small increase in sorbed $\mathrm{AH}_{2} \mathrm{DS}$ with decreasing $\mathrm{pH}$ was well below the 2.5 times increase in the reduction rate that occurred over this same $\mathrm{pH}$ interval (Figure 4).

The sorption of $\mathrm{Fe}(\mathrm{II})$ can decrease the rate and extent of microbial reduction of crystalline iron oxides (23) by consuming Fe(III) surface complexation sites and altering interfacial electrochemistry. In our experiments, the strong sorption of Fe(II) at pH 6.9 (Figure 1) was expected to decrease the concentration of surface sites for $\mathrm{AH}_{2} \mathrm{DS}$ adsorption and block underlying Fe(III) from electron transfer. The rigorous calculation of competitive $\mathrm{Fe}(\mathrm{II})$ and $\mathrm{AH}_{2} \mathrm{DS}$ sorption was not performed because of the unresolved problems with sorbate-specific site concentration, potential mineral pre- 


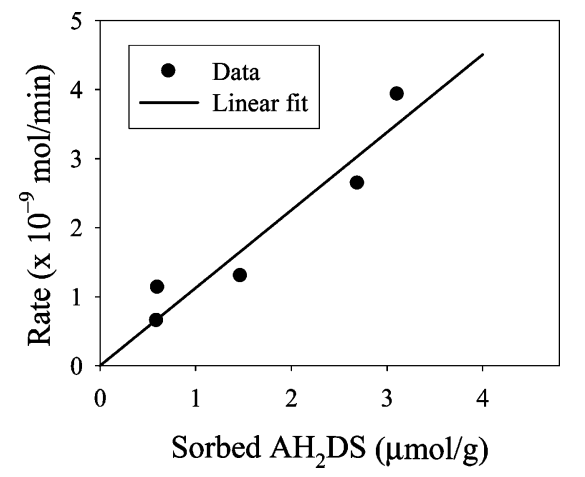

FIGURE 5. The rate of hematite reduction by $\mathrm{AH}_{2} \mathrm{DS}$ as a function of sorbed $\mathrm{AH}_{2} \mathrm{DS}$ concentration at $\mathrm{pH} 4.5$ and 6.9 calculated from competitive surface complexation of $\mathrm{Fe}(\mathrm{II}), \mathrm{AODS}$ and $\mathrm{AH}_{2} \mathrm{DS}$.

cipitation, and pH-buffer effects as discussed above. Approximate calculations of the competitive sorption of $\mathrm{AH}_{2} \mathrm{DS}$, AQDS, and $\mathrm{Fe}(\mathrm{II})$ at $\mathrm{pH} 4.5$ and 6.9 for hematite RP200M were performed as described in the Supporting Information. The calculated $\mathrm{AH}_{2} \mathrm{DS}$ surface complexation that considered competition from Fe(II) and AQDS was in linear correlation with the hematite reduction rate (Figure 5), as expected for reductant-promoted surface redox kinetics (e.g., ref 24).

The rate increase with decreasing $\mathrm{pH}$ may also relate to the redox reaction free energy. The electron-transfer rate of a redox reaction is proportional to its activation energy, which is proportional in a complex way to the reaction free energy based on the Marcus theory (25). Equation 3 indicated that the reaction free energy for the hematite reduction by $\mathrm{AH}_{2}-$ DS increased with decreasing $\mathrm{pH}$ under other same conditions. However, eq 3 is an overall redox reaction, and detail electron-transfer steps were unclear on hematite surfaces, preventing further discussion.

The measured rates of hematite reduction by $\mathrm{AH}_{2} \mathrm{DS}$ were faster than literature reports for hydroquinone. For example, the measured rate of $\mathrm{RP} 200 \mathrm{M}$ reduction at $\mathrm{pH} 4.5$ was 0.5 $\mu \mathrm{mol} / \mathrm{m}^{2} / \mathrm{min}$. This was larger than the reduction of hematite $\left(0.03 \mu \mathrm{mol} / \mathrm{m}^{2} / \mathrm{min}\right)$ at $\mathrm{pH} 2.5$ (26) and the reduction of goethite at $\mathrm{pH} 4.0\left(0.02 \mu \mathrm{mol} / \mathrm{m}^{2} / \mathrm{min}\right)$ by hydroquinone (22) . The more rapid reduction of hematite by $\mathrm{AH}_{2} \mathrm{DS}$ likely resulted from its lower half redox potential $\left(E_{0}=0.23 \mathrm{~V}\right)$ as compared to hydroquinone $\left(E_{0}=0.70 \mathrm{~V}\right)(20)$.

Influence of Flow Rate. The steady-state reduction rate increased with increasing flow rate except at $\mathrm{pH} 7.6$ (Figure $4 \mathrm{a})$, where the rates at different flow rates converged. Increasing the reactant flow rate decreased the residence time of all species. This increased aqueous and sorbed $\mathrm{AH}_{2}-$ DS concentrations and decreased Fe(II) and AQDS concentrations. The net result was that the reduction rate increased with increasing flow rate (Figure $4 \mathrm{a}$ ). The effect of flow rate was stronger at $\mathrm{pH} 4.5$ because the residence $\mathrm{AH}_{2} \mathrm{DS}$ concentration was low due to the fast oxidation by hematite. Increasing the flow rate increased the residence concentrations of $\mathrm{AH}_{2} \mathrm{DS}$ and decreased those of $\mathrm{Fe}(\mathrm{II})$ and AQDS. At higher $\mathrm{pH}$, however, the reduction rate was slower, and changes between the influent and effluent concentrations were less. Consequently, the changes of flow rate had a smaller effect on the residence concentrations and the reduction rates in the reactor.

Influence of $\mathrm{Fe}$ (II) and Phosphate. The rate of hematite reduction by $\mathrm{AH}_{2} \mathrm{DS}$ significantly decreased with increasing influent Fe(II) or phosphate concentration (Figure 4b,c). At $\mathrm{pH}$ 6.9, the reduction completely ceased when influent Fe(II) was over $0.14 \mathrm{mM}$ or influent $\mathrm{PO}_{4}{ }^{3-}$ was over $10 \mu \mathrm{M}$. At $\mathrm{pH} 4.5$, a larger amount of $\mathrm{Fe}(\mathrm{II})$ or phosphate was needed to decrease the reduction rate to the $\mathrm{pH} 6.9$ level. One hundred times less phosphate than Fe(II) was needed to

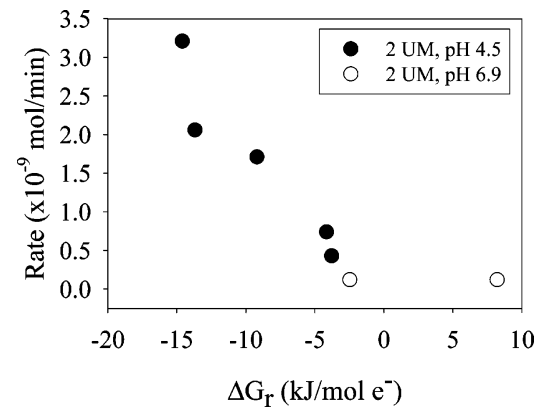

FIGURE 6. The rates of hematite reduction by $\mathrm{AH}_{2} \mathrm{DS}$ as a function of reaction free energy.

have the same inhibition effect on reduction. The stronger phosphate inhibition apparently resulted from its strong inner sphere complexation below $\mathrm{pH}_{\mathrm{PZNPC}}$ (27) that consumed surface complexation sites and reduced surface positive charge. This observation was, however, in contrast with goethite reduction by hydroquinone (22) that was only slightly affected by phosphate over the concentration range of $10^{-6}-$ $10^{-3} \mathrm{M} \mathrm{PO}_{4}{ }^{3-}$ at $\mathrm{pH}$ 3.3. Further studies are needed to resolve this inconsistency.

The presence of $\mathrm{Fe}(\mathrm{II})$ could affect the oxidation rate of $\mathrm{AH}_{2} \mathrm{DS}$ by surface site competition as described above or by decreasing reaction free energy. The decrease in hematite reduction rate with increasing influent $\mathrm{Fe}(\mathrm{II})$ at $\mathrm{pH} 4.5$ could not be explained by the competitive adsorption because Fe(II) sorption was negligible at pH 4.5 (Figure 1). Nor could it be explained by surface precipitation as speciation calculations at $\mathrm{pH} 4.5$ indicated that only the influent solution with $3.43 \mathrm{mM}$ Fe(II) was near saturation with magnetite. Thermodynamic calculation indicated a corresponding decrease in reduction rate with decreasing reaction free energy of eq 3 (Figure 6), suggesting the importance of reaction free energy on the electron-transfer rate as discussed before. The calculation of the reaction free energy was described in the Supporting Information.

Implication to Microbial Reduction of Iron Oxides. The microbial reduction of iron oxides under anaerobic conditions in the presence of a quinone-containing ESC apparently consists of two steps in series: bioreduction of the ESC followed by the abiotic, heterogeneous reduction of the iron oxide by the reduced ESC. The overall kinetic rate of iron oxide reduction, in this circumstance, will be determined by the slower of the two kinetic reactions. At circumneutral $\mathrm{pH}$, which is optimal for many DIRB, the abiotic step is expected to be rate-limiting because $\mathrm{Fe}(\mathrm{II})$ is produced that competes for surface sites and lowers reaction free energy. The observed accumulation of $\mathrm{AH}_{2} \mathrm{DS}$ during the microbial reduction of hematite in presence of AQDS (9) was consistent with the rate-limiting role of the abiotic step as determined by this research. ESC-facilitated microbial reduction of Fe(III) oxide would cease when the abiotic reaction series approaches equilibrium, or the sorption of ESC on the iron oxides becomes negligible through competitive effects.

The sorption of $\mathrm{AH}_{2} \mathrm{DS}$ was weak on $\alpha-\mathrm{Al}_{2} \mathrm{O}_{3}$ and on hematite by analogs. Consequently $\mathrm{AH}_{2} \mathrm{DS}$ sorption could be strongly influenced by strongly sorbing cations and anions. Phosphate is, in particular, an important consideration in microbial reduction of iron oxides because of its strong sorptivity, apparent influence on interfacial electron transfer (28), and inhibitory role in magnetite formation (29). Phosphate is an essential bacterial nutrient and is commonly used in media for mineral-microbe experiments. The presence of $\mathrm{PO}_{4}{ }^{3-}$ may result in a large variability in both rate and extent of ESC-facilitated microbial reduction of iron oxides depending on its concentration and the Fe(III) oxide surface properties. 


\section{Acknowledgments}

This research was supported by the office of Basic Energy Science (BES), U.S Department of Energy (DOE). The Pacific Northwest National Laboratory is operated for DOE by Battelle Memorial Institute under contract DE-AC0676RL01830. Research was performed in the Environmental Molecular Sciences Laboratory (EMSL), a national scientific user facility sponsored by the Department of Energy's Office of Biological and Environmental Research and located at the PNNL.

\section{Supporting Information Available}

Fe(II) surface complexation model and parameters; the Langmuir model and parameters for AQDS and $\mathrm{AH}_{2} \mathrm{DS}$ sorption; calculation of competitive sorption of Fe(II), AQDS, and $\mathrm{AH}_{2} \mathrm{DS}$; calculation of redox reaction free energy; AQDS and $\mathrm{AH}_{2} \mathrm{DS} \mathrm{UV}$-vis spectra and extinction coefficients; tabulated original data of reduction rates of hematite by $\mathrm{AH}_{2}-$ DS; and acid-base and electrolyte titration results. This material is available free of charge via the Internet at http:// pubs.acs.org.

\section{Literature Cited}

(1) Lovley, D. R. Dissimilatory Fe(III) and Mn(IV) reduction. Microbiol. Rev. 1991, 55, 259-287.

(2) Fredrickson, J. K.; Gorby, Y. A. Environmental processes mediated by iron-reducing bacteria. Curr. Opin. Biotechnol. 1996, 7, 287-294.

(3) Childers, S. E.; Ciufo, A.; Lovley, D. R. Geobacter metallireducens accesses insoluble Fe(III) oxide by chemotaxis. Nature 2002, 416, 767-769.

(4) Nevin, K. P.; Lovley, D. R. Mechanisms for accessing insoluble $\mathrm{Fe}(\mathrm{III})$ oxide during dissimilatory $\mathrm{Fe}(\mathrm{III})$ reduction by geothrix fermentans. Appl. Environ. Microbiol. 2002, 68, 2294-2299.

(5) Newman, D. K.; Kolter, R. A role for excreted quinones in extracellular electron transfer. Nature 2000, 405, 94-97.

(6) Lovley, D. R.; Coates, J. D.; Blunt-Harris, E. L.; Phillips, E. J. P.; Woodward, J. C. Humic substances as electron acceptors for microbial respiration. Nature 1996, 382, 445-448.

(7) Scott, D. T.; Mcknight, D. M.; Blunt-Harris, E. L.; Kolesar, S. E.; Lovley, D. R. Quinone moieties act as electron acceptors in the reduction of humic substances by humic-reducing microorganisms. Environ. Sci. Technol. 1998, 32, 2984-2989.

(8) Zachara, J. M.; Fredrickson, J. K.; Li, S.-M.; Kennedy, D. W.; Smith, S. C. Bacterial reduction of crystalline Fe(III) oxides in single phase suspensions and subsurface materials. Am. Miner. 1998, 83, 1426-1443.

(9) Royer, R. A.; Burgos, W. D.; Fisher, A. S.; Unz, R. F.; Dempsey, B. A. Enhancement of biological reduction of hematite by electron shuttling and Fe(II) complexation. Environ. Sci. Technol. 2002, 36, 1939-1946.

(10) Sugimoto, T.; Muramatsu, A.; Sakata, K.; Shindo, D. Characterization of hematite particles of different shapes. J. Colloid Interface Sci. 1993, 158, 420-428.

(11) Kosmulski, M. Chemical Properties of Material Surfaces; Marcel Dekker, Inc.: New York, 2001.

(12) Liger, E.; Charlet, L.; van Cappellen, P. Surface catalysis of uranium(VI) reduction by iron(II). Geochim. Cosmochim. Acta 1999, 63, 2939-2955.
(13) Stookey, L. L. Ferrozine - A new spectrophotometric reagent for Iron. Anal. Chem. 1970, 42, 779-781.

(14) Jeon, B.-H.; Dempsey, B. A.; Burgos, W. D.; Royer, R. A. Reactions of ferrous iron with hematite. Colloid Surf., A 2001, 191, 41-55.

(15) Larese-Casanova, P.; Scherer, M. M. Fe(II) sorption on hematite: New insights based on spectroscopic measurements. Environ. Sci. Technol. 2007, 41, 471-477.

(16) Turner, L. J.; Kramer, J. R. Irreversibility of sulfate sorption on goethite and hematite. Water, Air, Soil Pollut. 1992, 63, 2332.

(17) Scamehorn, J. F.; Schechter, R. S.; Wade, W. H. Adsorption of surfactant on mineral oxide surfaces from aqueous solutions: I Isomerically pure anionic surfactants. J. Colloid Interface Sci. 1982, 85, 463-478.

(18) Han, K. N.; Healy, T. W.; Fuerstenau, D. W. The mechanism of adsorption of fatty acids and other surfactants at the oxidewater interface. J. Colloid Interface Sci. 1973, 44, 407-414.

(19) Stack, A. G.; Eggleston, C. M.; Engelhard, M. H. Reaction of hydroquinone with hematite I: Study of adsorption by electrochemical-scanning tunneling microscopy and X-ray photoelectron spectroscopy J. Colloid Interface Sci. 2004, 274, 433441.

(20) Clark, W. M. Oxidation-Reduction Potentials of Organic Systems; The Williams \& Wilkins Company: Baltimore, MD, U.S.A., 1960 .

(21) Gamage, R. S. K. A.; McQuillan, A. J.; Peake, B. M. Ultravioletvisible and electron paramagnetic resonance spectroelectrochemical studies of the reduction products of some anthraquinone sulphonates in aqueous solutions. J. Chem. Soc. Faraday Trans. 1991, 87, 3653-3660.

(22) LaKind, J. S.; Stone, A. T. Reductive dissolution of goethite by phenolic reductants. Geochim. Cosmochim. Acta 1989, 53, 961971.

(23) Roden, E. E.; Urrutia, M. M. Ferrous iron removal promotes microbial reduction of crystalline iron(III) oxides. Environ. Sci. Technol. 1999, 33, 1847-1853.

(24) Stumm, W. Chemistry of the Solid-Water Interface; WileyInterscience, John Wiley \& Sons, Inc.: 1992.

(25) Bard, A. J.; Faulkner, L. R. Electrochemical Methods: Fundamentals and Applications; Wiley: New York, 1980.

(26) Stack, A. G.; Rosso, K. M.; Smith, D. M. A.; Eggleston, C. M. Reaction of hydroquinone with hematite II: Calculated electrontransfer rates and comparison to the reductive dissolution rate. J. Colloid Interface Sci. 2004, 274, 442-450.

(27) Goldberg, S.; Sposito, G. A chemical model of phosphate adsorption by soils. Reference oxide minerals. Soil Sci. Soc. Am. J. 1984, 48, 779-783.

(28) Borch, T.; Masue, Y.; Kukkadapu, R. K.; Fendorf, S. Phosphate imposed limitations on biological reduction and alteration of ferrihydrite. Environ. Sci. Technol. 2007, 41, 166-172.

(29) Kukkadapu, R. K.; Zachara, J. M.; Fredrickson, J. K.; Kennedy, D. W. Biotransformation of synthetic 2-line silica-ferrihydrite coprecipitates by a dissimilatory Fe(III)-reducing bacterium: Formation of greenrust in the presence of phosphate. Geochim. Cosmochim. Acta 2004, 67, 1081-1087.

Received for review April 1, 2007. Revised manuscript received July 13, 2007. Accepted September 7, 2007.

\section{ES070768K}

